\title{
感光性結晶化ガラス上への銅めっき膜の形成
}

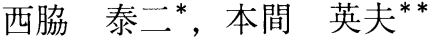

\section{Formation of Copper Plating Films on Photosensitive-Crystallizable Glass Surface}

Taiji NISHIWAKI* and Hideo HONMA**

\author{
*関東学院大学大学院（テ236-0032 神奈川県横浜市金沢区六浦町4834） \\ **関東学院大学工学部（元236-0032 神奈川県横浜市金沢区六浦町4834） \\ *Graduate School, Kanto Gakuin Univ. (4834 Mutsuura-cho, Kanazawa-ku, Yokohama-shi, Kanagawa 236-0032) \\ **Fac.of Eng., Kanto Gakuin Univ. (4834 Mutsuura-cho, Kanazawa-ku, Yokohama-shi, Kanagawa 236-0032)
}

\begin{abstract}
概要 感光性結晶化ガラスは立体的，微細加工が可能であるため，エレクトロニクス分野での幅広い応用が期待される。 従来, ガラス上への回路用導電膜はドライプロセスにより形成されてきた。しかしながら, ドライプロセスでは, 立体的, 複 雑形状の基板には均一な成膜は困難である。本研究では, エッチング後の感光性結晶化ガラスの表面形態とガラス素材上の銅 めっき膜の密着性を検討した。ガラス表面はガラスと銅めっき膜の間の密着強度を改善するためにフッ化物をべースとしたエ ッチング液で適切に粗化した。エッチング特性は結晶化の状態によりまったく異なった。非晶質状態, 完全結晶質状態の感光 性結晶化ガラスでは, 銅めっき膜とガラスの密着強度を改善する適切なエッチング形態が得られた。完全結晶化状態では, 低 濃度のフッ化水素酸での処理でアンカーサイトの形成がなされ, 銅めっき膜とガラス表面の密着強度は $1.7 \mathrm{kgf}{ }^{\prime} 4 \mathrm{~mm}^{2}$ 程度で あった。優れた密着強度は結晶質中の $\mathrm{Li}_{2} \mathrm{O} \cdot \mathrm{SiO}_{2}$ に富んだ部分を優先的にエッチングすることで得られるアンカー効果による ものと考えられる。
\end{abstract}

\begin{abstract}
Photosensitive-Crystallizable glass (PC-glass) is expected to be applied widely in electronics field because it forms three-dimensional and complicated shape easily. Conductive films on glass have been formed conventionally by dry process. However, it is very difficult to obtain the uniform metal deposition on the third-dimensional configuration by dry process. In our investigation, PC-glass surface morphology after etching and adhesion of copper plating films on a glass substrate are examined. The glass surface was appropriately roughened by fluoride-based etchant to improve the adhesion strength between glass and copper plating film. The etching characteristics were entirely different from crystallization conditions. Amorphous and fully crystallized PC-glasses were provided to obtain the proper etching morphologies for improvement of the adhesion strength between copper plating films and glass. Under fully crystallized condition, formation of anchor sites was created by the treatment in dilute hydrofluoric acid, and adhesion strength between copper plating films and glass surface was around $1.7 \mathrm{kgf} / 4 \mathrm{~mm}^{2}$. Excellent adhesion strength is derived from the anchor effect that is created by the preferential etching at $\mathrm{Li}_{2} \mathrm{O} \cdot \mathrm{SiO}_{2}$ riched parts in crystalline substrate.
\end{abstract}

Key Words: Adhesion Strength, Etching, Glass Matrix, Photosensitive-Crystallizable Glass

\section{1. 緒 言}

ガラスは加工性, 可視光透過性, 電気絶縁性などの優れ た特性のため, エレクトロニクスの分野でも，ガラス IC 基板や液晶ディスプレイ等, 幅広く使用されている。ガラ ス材料の中でも感光性結晶化ガラスは立体的, 複雑な形状 に加工が可能であり, 今後エレクトロニクス分野において 基板材料等，広範囲での応用が期待できる。回路形成を目 的としたガラス基板材料への導電膜形成には, 従来からド ライプロセスが用いられてきた。しかしながら，ドライプ ロセスでは機器の小型化あるいは大型化, 高機能化に伴う 立体的複雑な形状の基板に対して均一な成膜は困難であ
り，また，大型基板に対しては莫大な設備投資を必要とす る。そこで本研究では, 量産性に優れ, 立体的複雑な形状 の基板に対して均一な成膜が可能であるウエットプロセス を適応し，ガラスのエッチング特性および銅めっき膜の密 着性について検討した。

近年，機器の小型化に伴い配線の低抵抗化，導電金属の 厚膜化の要求が高まっている。われわれは過去より平滑な ガラスに対し，密着性に優れためっき膜の形成について報 告してきだ1.2)。それをもとに無電解めっきのみを用いて平 滑なガラス面への検討を行ったところ，密着性に優れた厚 膜形成は困難であった。そこで，本研究では，フッ化物系 エッチング夜を用いてガラスの表面を粗化し, 厚膜化した 
( I ) Photosensitive-crystallizable glass [Amorphous condition]

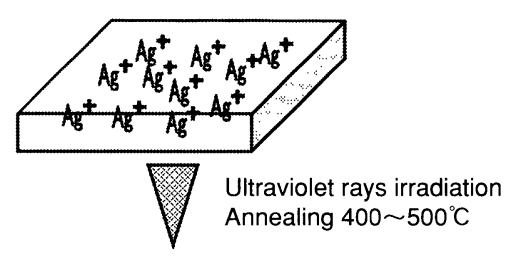

( II ) First crystallization

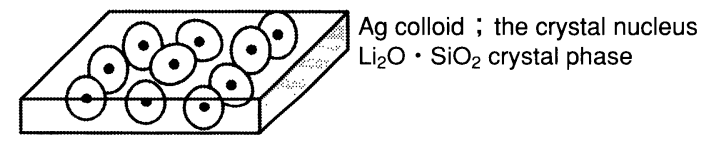

Annealing $800^{\circ} \mathrm{C}$

( III) Second crystallization [Crystalline condition]

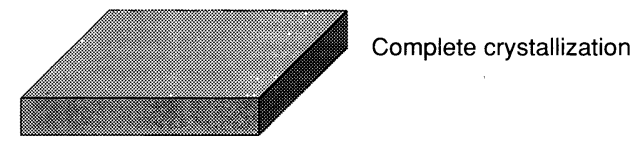

Fig.1 Model of crystallization process of PC-glass

銅めっき膜との密着性について検討を行った。

今回使用した感光性結晶化ガラスは立体的, 微細加工が 可能であるため, エレクトロニクス分野での幅広い応用が 期待される。

感光性結晶化ガラス ( $\mathrm{LiO}_{2}-\mathrm{SiO}_{2}$ 系) の結晶化工程をFig. 1 に示す。(I)未感光のガラスに紫外線を照射, 熱処理を 行うことで( II $) \mathrm{Li}_{2} \mathrm{O} \cdot 2 \mathrm{SiO}_{2}$ などのフッ酸に対する溶解速度 が数十倍速い結晶が照射部分のみに析出する。この特徵を 生かして複雑な形状の加工が可能となっている。(III)さら に高温で熱処理すると完全に結晶化が進行し, 非晶質時の ガラスと比較して機械的強度に優れた多結晶体セラミック スとなる゙๋。

本報では( I )の未感光（以後, 非晶質状態と称す）の感 光性結晶化ガラスと, (III)の完全結晶化後 (以後, 結晶質 状態と称す）のガラスの 2 種類を使用し，ガラスのエッチ ング形態と銅めっき膜の密着性を調査した。

\section{2. 実験方法}

試験片として, 非晶質および結晶質状態の感光性結晶化 ガラス ( $\mathrm{Li}_{2} \mathrm{O}-\mathrm{Al}_{2} \mathrm{O}_{3}-\mathrm{SiO}_{2}$ 系) $1.5 \times 3.0 \mathrm{~cm}$ ( $1 \mathrm{~mm}$ 厚) を使 用した。また, Table 1 に示すエッチング液組成および条 件を使用じ， Table 2 に示す工程を用いた。無電解銅めっ きには, 予備検討において, 従来使用されているホルムア ルデヒドを還元剤としためっき浴より優れた密着性を示し た，次亜リン酸塩を還元剂としためっき液らを使用した。 また, 電解めっきは銅めっき皮膜の応力を抑制するため, フレキシブル基板用の光沢剂を添加したハイスロー硫酸銅 めっき浴を使用した。無電解めっきにより導電膜を $0.3 \mu \mathrm{m}$ 形成した後, 電解めっきにより約 $10 \mu \mathrm{m}$ の銅めっき膜を形
Table 1. Etching bath composition and condition

\begin{tabular}{|c|c|c|}
\hline (a) & $\begin{array}{l}\cdot \overrightarrow{H F} \\
\cdot \mathrm{NH}_{4} \mathrm{~F} \cdot \mathrm{HF}\end{array}$ & $\begin{array}{l}1 \sim 10 \mathrm{wt} \% \\
1 \sim 10 \mathrm{wt} \%\end{array}$ \\
\hline & Temp. $\left({ }^{\circ} \mathrm{C}\right)$ & R.T. \\
\hline (b) & {$\left[\begin{array}{l}\mathrm{NH}_{4} \mathrm{~F} \cdot \mathrm{HF} \\
\mathrm{KF}\end{array}\right.$} & $\begin{array}{l}5 \sim 20 \mathrm{wt} \% \\
5 \sim 20 \mathrm{wt} \%\end{array}$ \\
\hline & Temp. $\left({ }^{\circ} \mathrm{C}\right)$ & 70 \\
\hline
\end{tabular}

Table 2. Experimental process

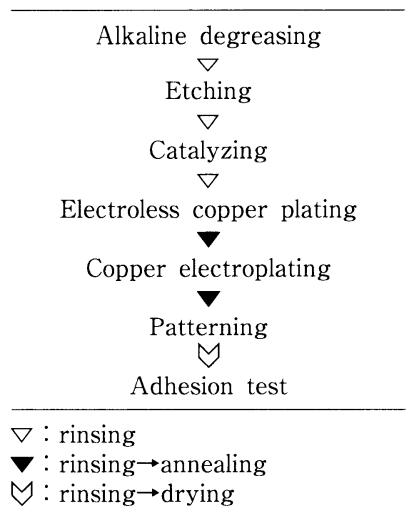

成した。

エッチング後の表面および断面観察には走査型電子顕微 鏡（日本電子JSM-5300LV；以降SEMとする）および形状 測定機（Teylor-Hobson Ltd. Form Talysurf Series2), 元 素分析にはエネルギ分散型 X 線分析装置（日本電子JED2001 ；以後EDSとする）およびICP発光分析装置（SEIKO INSTRUMENT SPS-8000）を使用した。また，銅めっき 膜の密着強度は, $2 \times 2 \mathrm{~mm}$ のパッドを形成し, 直径 $0.8 \mathrm{~mm}$ の銅線をはんだ付けした後, インストロンテス夕 （丸菱科学機械製作所SV-950）を用いてL字型ピール強度 試験6により測定した。

\section{3. 実験結果および考察}

\section{1 エッチング特性の検討}

3. 1.1 フッ化物単体溶液によるエッチング

ガラスの表面を粗化するため, フッ化水素酸 (Hydrofluoric Acid 以後HF) またはフッ化水素アンモ ニウム (Ammonium Hydrogen Fluoride 以後AHF) 単 体水溶液を用いて，エッチング処理を行った。その結果， エッチング後のガラスの表面形態は, 両者ともにほとんど 差異がなかった。その代表例として HF単体水溶液を使用 してエッチングしたガラスの表面形態をFig. 2 に示す。そ の結果, 非晶質状態の場合, ほぼ均一にエッチングされ, アンカー効果の期待できる表面形態の形成は困難と判断し た。一方, 結晶質状態のガラスでは, 非晶質状態時と異な り, 非常に低濃度の場合でも容易に粗化され, 粗雑な表面 形態の作製が可能であった。このことから非晶質状態では ガラスがほほ均一に溶解し, 結晶質状態では $\mathrm{Li}_{2} \mathrm{O} \cdot \mathrm{SiO}_{2}$ 結 晶に富んだ部分が優先的に溶解していることが推察され 


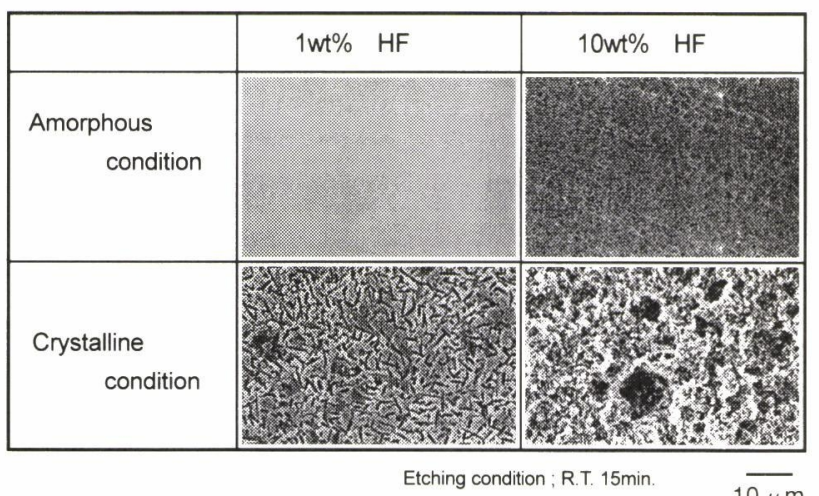

Fig.2 SEM images of each PC-glass surfaces

る。

3. 1.2 フッ化物混合系溶液によるエッチング

非晶質状態においてもアンカー効果が得られる表面を形 成するため，KF-AHF混合エッチング液（Table 1 (b)）で エッチング処理を行った。処理後の表面形態をFig. 3 に示 す。非晶質状態のガラスであっても表面に選択的な凹凸形 成が可能であり，エッチング組成により表面形態は異なっ た。続いてEDSによりエッチング後のガラス表面の元素 分析を行った結果をFig. 4 に示す。エッチング後の表面に は素材に含有される比率以上のKが検出され, ガラス表面 で難溶性のKを含む化合物層が形成されたと推察できる。 また，粗さ測定結果をFig. 5 に示したが，エッチング部は 非エッチング部と比較し，ほとんど表面の高さの減少は認 められず，さらに非エッチング部より隆起している部分が 存在した。この結果からも化合物層の生成が示唆された。

このようなガラス表面の状態変化から, エッチングの進 行モデルをFig. 6 に推定した。すなわち $\mathrm{HF} に よ り ~ \mathrm{SiO}_{2}$ が溶 解したのち (Fig. 6 (1))，難溶性フッ化物がガラス表面に 局在化しながら蓄積され（Fig. 6 (2)），この化合物層がそ の後のエッチング液との接触を阻害し, その隙間を通して 選択的エッチングが進行する（Fig. 6 (3)）と推測できる。 ここで生成した難溶性の化合物層は密着性に奇与しないた め, 以後の検討ではエッチング後に超音波洗浄を行い, 化 $(w t \%)$

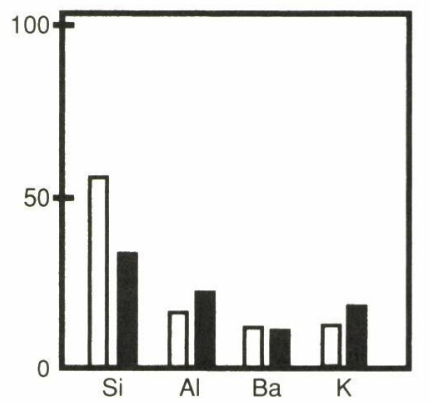

$20 \mathrm{wt} \%-H F+5 w t \%-A H F \quad 70^{\circ} \mathrm{C} 15 \mathrm{~min}$.

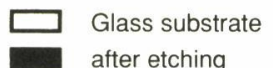

Fig.4 EDS analysis results for glass surface

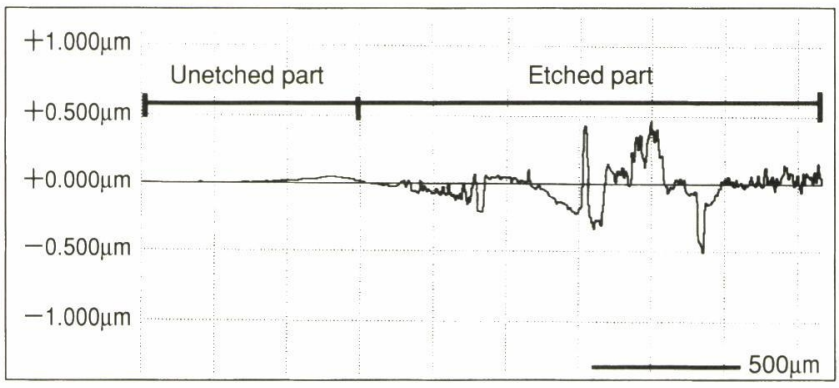

Etching condition ; 20wt\%-KF + 5wt\%-AHF $70^{\circ} \mathrm{C} 15 \mathrm{~min}$.

Fig.5 Measurement result of glass surface after etching [Amorphous condition]

合物層を除去した。

\section{2 めっ膜の密着強度}

ガラス表面を 3.1 に示した条件でエッチング処理した後, 銅めっき膜を約 $10 \mu \mathrm{m}$ 形成し，その密着強度を測定した。

非晶質状態のガラスにおいて, HF, AHF単体水溶液で エッチングした表面に銅めっき膜を形成した場合，ほとん ど密着性はなく, 密着強度の測定は困難であった。つぎに $\mathrm{AHF}$ - KFF混合系エッチング液を使用したエッチング表面 に対する密着強度を測定したところ，Fig. 7 に示したよう に10wt\%-KF+ $5 \mathrm{wt} \%-\mathrm{AHF}$ 組み合わせで最大 $0.5 \mathrm{kgf} /$

I ) Change of KF concentration ( with 5wt\%-AHF )

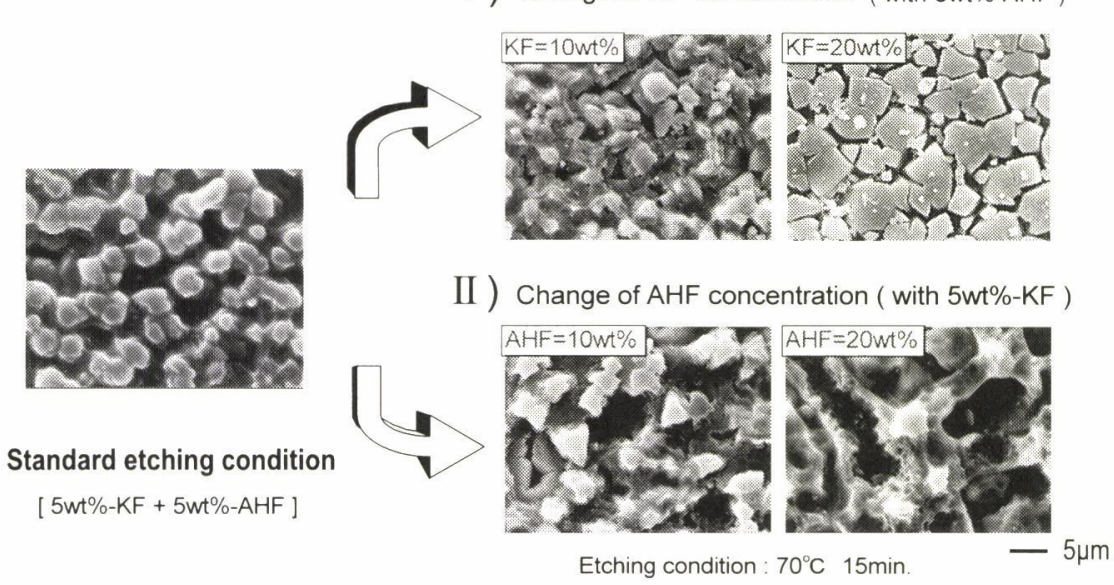

Fig.3 Relationship between each composition of etching solution and surface morphologies [Amorphous condition] 

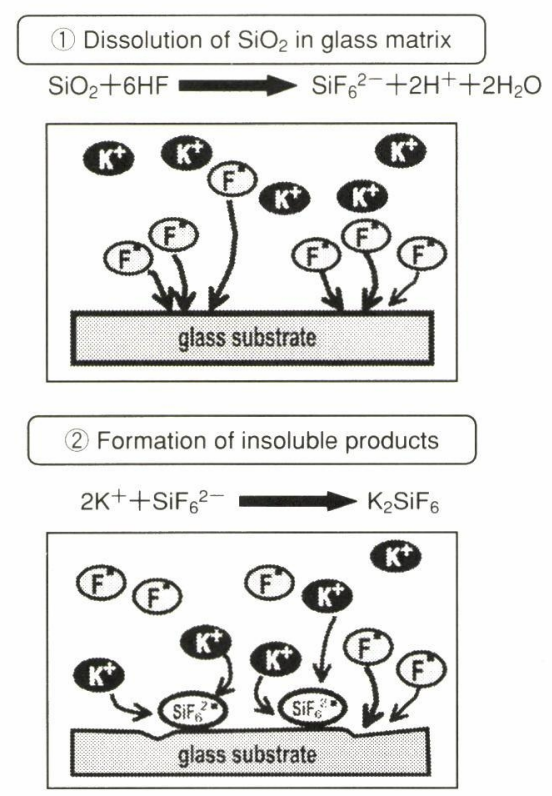

(3) Blocking the etching by fluoride salt

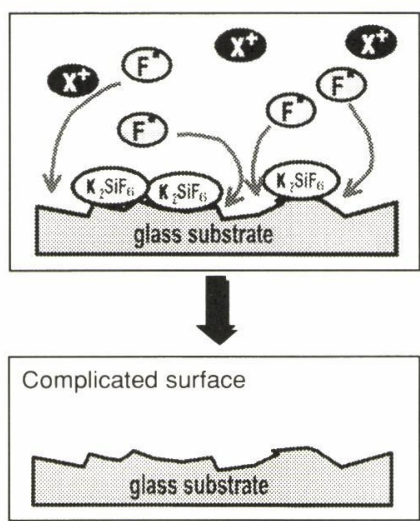

Fig.6 Reaction mechanism of KF-AHF etching solution with amorphous PC-glass

$4 \mathrm{~mm}^{2}$ となった。めつき後の断面写真をFig. 8 に示す。

比較的良好な密着性を示した条件 [Fig. 8 (a), (c)] はア ンカーサイトを有していた。一方, エッチング溝が浅い場 合, Fig. 8 (d)のようにアンカー効果が得られない。また, Fig. 8 (b)のようにアンカーサイトを有する場合であっても エッチングによりガラス自体の強度が低下すると密着力が 得られなかった。

続いて, 結晶質状態のガラスと銅めつき膜の密着強度お よびめっき後の断面観察結果をそれぞれFig. 9, Fig.10に 示す。

$1 \mathrm{wt} \%$-HFを使用した場合，エッチング時間に比例し て密着強度も増加し, 最大で $1.7 \mathrm{kgf} / 4 \mathrm{~mm}^{2}$ と非晶質状態と 比較し 3 倍以上の優れた密着性を示した。すなわち微細な エッチング痕を多数有し, その底部まで銅めっき膜が形成 されたことによるアンカー効果に起因すると考えられる。 $1 \mathrm{wt} \%$-AHFを用いた場合, 密着強度はエッチング時間30 分時で密着強度が最大值を示し, その後, オーバーエッチ ングによりガラス自体のマトリクスが脆弱し密着が低下す る傾向を示した。
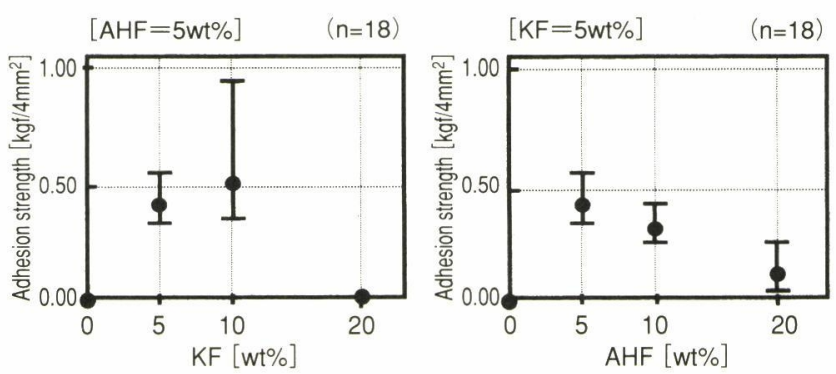

Fig.7 Effect of each etching composition on adhesion strength [Amorphous condition]

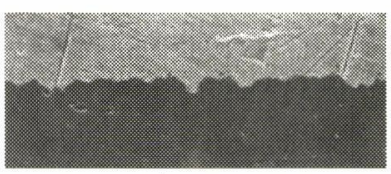

a) $5 \mathrm{wt} \%-\mathrm{KF}+5 \mathrm{wt} \%-\mathrm{AHF}$

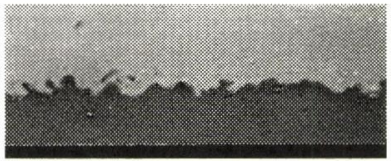

c) $10 \mathrm{wt} \%-\mathrm{KF}+5 \mathrm{wt} \%-\mathrm{AHF}$

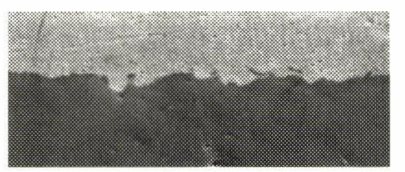

b) $5 w t \%-K F+10 w t \%-A H F$

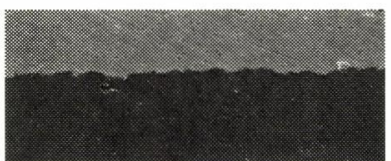

d) $20 w t \%-K F+5 w t \%-A H F$
Fig.8 SEM images of cross sectional views for each sample [Amorphous condition]

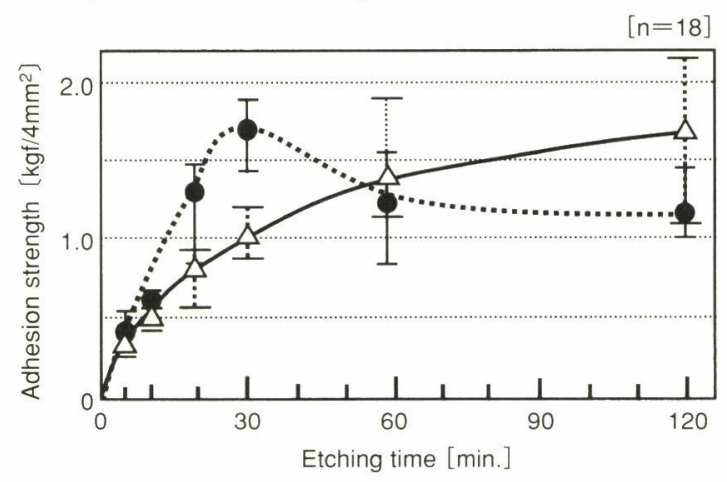

$\triangle: 1 w t \%-H F \quad: 1 w t \%-A H F$

Fig.9 Relationship between etching time and adhesion strengths on glass [Crystalline condition]

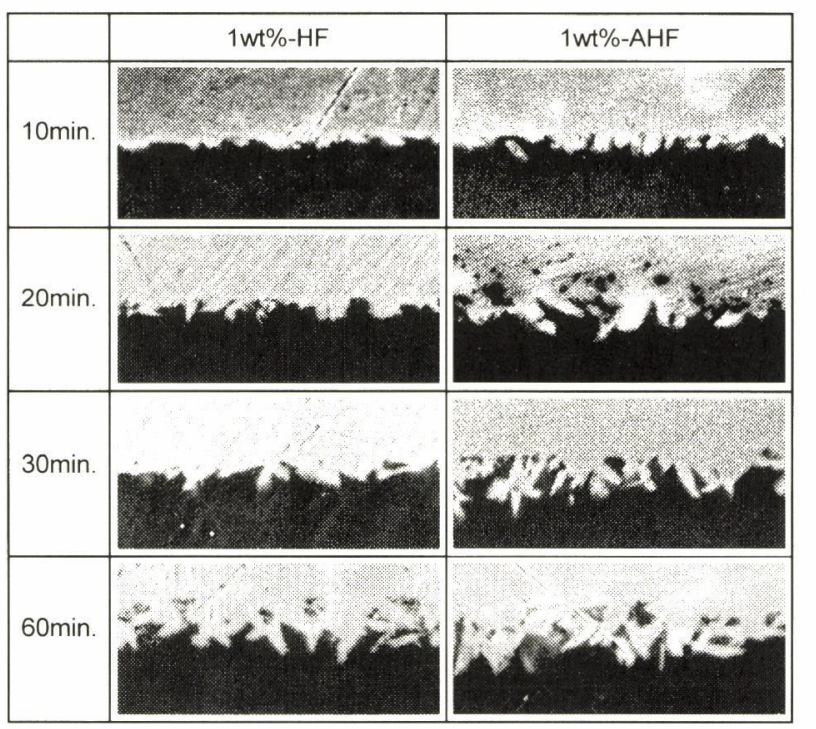

Fig.10 SEM images of cross sectional views for each samples [Crystalline condition] 
このように，ともにエッチング痕の底部まで銅めっき膜 が形成されているにもかかわらず，ガラスの結晶化の状態 によって，銅めっき膜の密着強度が大きく異なる原因は, ガラスが結晶化することでクラックが結晶粒界で停止し, 破壊が抑制されるためと考えられる。

\section{4. 結 語}

感光性結晶化ガラスのエッチング特性㧍よび銅めっき膜 の密着性に関する因子を検討した結果, 以下の結論を得た。

1. 結晶化の状態によってエッチング特性は異なり, 結 晶質状態では低濃度のフッ酸でガラス表面の選択的な溶解 が可能であり, 容易にアンカー効果の期待できる複雑なエ ッチング痕を形成できた。

2. 非晶質状態ではAHFとフッ化カリウムの混合溶液を 使用することで複雑なエッチング痕を形成できた。そのエ ッチング機構はガラス表面で難溶性フッ化物がガラス表面 に局在化しながら生成し，その化合物層の隙間を通して選 択的なエッチングにより進行すると推測される。

3. エッチング後のガラスと銅めっき膜の密着強度は非 晶質状態では $0.5 \mathrm{kgf} / 4 \mathrm{~mm}^{2}$, 一方, 結晶質では $1.7 \mathrm{kgf} /$ $4 \mathrm{~mm}^{2}$ の優れた密着強度を示したが, 共にガラス内から破 断していた。ガラスと銅めっき膜間でほぼ実用的な密着強
度を得ることができた。

4. 結晶質状態では $\mathrm{Li}_{2} \mathrm{O} \cdot \mathrm{SiO}_{2}$ に富んだ部分が選択的に エッチングされることでアンカー効果が得られ, さらに多 結晶体の粒界で破壊に伴うクラックの進行が抑制されるこ とで非晶質状態と比較して優れた密着強度が得られたと考 えられる。

(2000.7.25-受理２000.10.25-再受理）

\section{文献}

1) 堀田慎一, 鈴木佳司, 本間英夫 : “ガラスと無電解ニッケル めっきの密着性”，表面技術，Vol.44，No.10，p.831， 1993

2) H.Honma, S.Hotta and H.Watanabe: "Fabrication of Nickel Film on Glass Disk by Electroless Nickel Plating", Plating and Surface Finishing, Vol.82, No.1, pp.60-62, 1995

3) ニューガラスハンドブック編集委員会 : “ニューガラスハン ドブック”，丸善，pp.216〜221，1991

4) 太田秀夫, 伊藤康則, 他 : 特開平5-345637

5）水口泰一, 小林 健, 藤波知之, 本間英夫：“次亜リン酸を 還元剤とする無電解銅めっきによる導体層一絶縁樹脂層の 密着性”，表面技術，Vol.49，No.12，p.1327，1998

6）渋谷智德，本間英夫： “シリコンウェハー上の無電解めっき の密着性”，表面技術，Vol.37，No.8，p.563，1986 